\title{
Servidor da mesa da Palavra de Deus: estudo teológico-pastoral sobre o ministério do diácono permanente
}

\author{
Orientador: Abimar Oliveira de Moraes \\ Doutorando: Julio Cesar Bendinelli \\ Área de Concentração: Teologia Sistemático-Pastoral \\ Linha de Pesquisa: Fé e Cultura
}

A missão do diácono permanente como servidor da mesa da Palavra e sua contribuição à atual demanda da Igreja no campo da Evangelização. A investigação, que parte dos textos exarados pelo Concílio Vaticano II e alcança os documentos magisteriais pós-conciliares, tem como objetivo apresentar a teologia da mesa da Palavra em sua relação com a anúncio do evangelho com o fito de valorizar o exercício do munus docendi ecclesiae conferido ao diácono permanente em virtude de sua ordenação sacramental. Baseia-se na pesquisa bibliográfica das fontes indicadas nas referências e se apresenta em três capítulos. O primeiro capítulo é dedicado a teologia da mesa da palavra de Deus em sua relação com o anúncio do Evangelho. Investiga o significado prático da recuperação conciliar da noção de unidade das "duas mesas" - Palavra e Eucaristia, com a decorrente revalorização do lugar reservado à Palavra de Deus na liturgia e na vida dos fieis. Busca pela presença das expressões mensa verbi Dei e pão da Palavra na Tradição eclesial e pelo lugar da Palavra de Deus em contexto litúrgico-celebrativo. Analisa os elementos dos ritos de ordenação e suas implicações práticas para o serviço à Palavra de Deus. O segundo capítulo trata do ministério do diácono permanente como restaurado pelo Concílio Vaticano II. Examina a similaridade e a distinção entre os ministérios ordenados e os não-ordenados. Verifica as funções conferidas pela ordenação. Investiga elementos do serviço à pregação desde a origem do ministério diaconal no Novo Testamento e apresenta a essência e a identidade do ministério dos diáconos. O terceiro capítulo propõe caminhos para que o diácono permanente possa contribuir na esfera da evangelização, interpretando os resultados das investigações procedidas nos capítulos anteriores. Aponta 
então áreas onde o ministério diaconal pode colaborar na atual demanda missionária e evangelizadora da Igreja nos campos da martyria, koinonia e leitourgia. Conclui que o encargo diaconal no campo da evangelização tem sido muito pouco aproveitado, incentivado ou valorizado na Igreja e na sociedade. Sendo assim, os diáconos devem assumir a parcela de serviço que lhes cabe como mensageiros da Palavra, pois certamente tem mais funções no âmbito da pregação e do ensino do que atualmente exercem, haja vista que tudo quanto se refere à pregação do evangelho, à catequese, à difusão da Bíblia e sua explicação ao povo lhes foi conferido ordinariamente.

Palavras-chave: Diaconato permanente. Mesa da Palavra de Deus. 